\title{
Joining of Aluminum and Steel using AlSi 12 Brazing Filler in a Protective Atmosphere Furnace: Microstructure and Mechanical Properties
}

\author{
Yijun Man*, Dayou Pan, Shibo Liu \\ Singapore Institute of Manufacturing Technology, 73 Nanyang Drive, Singapore 637662 \\ *Corresponding author: Yijun Man, E-mail: MAN_Yijun@simtech.a-star.edu.sg
}

DOI: $10.37155 / 2717-526 \mathrm{X}-0302-2$

\begin{abstract}
Brazing of pure aluminum (Al) to steel using an Al-12 wt. \%Si (AlSi12) filler metal and an Al brazing flux was performed in furnace filled with protective atmosphere. Microstructure characterizations of the full/ fractured joints, tensile shear strength and micro-hardness tests were performed on the samples with holding time from 5-30 min at brazing temperature of $600{ }^{\circ} \mathrm{C}$ and additional thermal exposure of $30 \mathrm{~min}$ at temperature of $480^{\circ} \mathrm{C}$. It is found that the joint seam for all samples features roughly into four layers, among them, the layer adjacent to steel is an IMC layer and dominantly distributed with $\eta$ phase. The tensile shear strength of joints is inversely proportional to the thickness of $\eta$ phase layer and particularly governed by a specific zone which is located in the $\eta$ phase layer, directly adjacent to the interface between $\eta$ phase layer and steel and scattered with a lot of visible pores and cracks. Micro-hardness tests show the hardness of the $\eta$ phase layer remains the highest for each holding time and increases with the increase of holding time. The higher hardness leads to the limited plasticity of the $\eta$ phase and more fragile of this layer. Furthermore, great differences of hardness exist between the $\eta$ phase layer and steel may also generate great stresses that induce the crack initiation in the specific zone and finally result in the failure of brazed joints.

Keywords:Furnace brazing; Dissimilar material; Pure aluminum; Steel; Al-12 wt. \%Si filler metal; Flux; Intermetallic compounds (IMCs); Tensile shear strength; Microstructure; Micro-hardness

\section{Introduction}

Joining of dissimilar materials is of special interest for automotive, shipbuilding and aerospace manufacturers because its lightweight characteristics reduce the structural weight of vehicles, ships and passenger aircrafts, increasing fuel efficiency and reducing $\mathrm{CO}_{2}$ emissions. The high strengthto-weight ratio, formability, long-term durability,

corrosion resistance, recycling efficiency and other good properties of $\mathrm{Al} / \mathrm{Al}$ alloys are often desired in combination with the high strength, hardness, erosion resistance and elasticity of steels. The engineering applications of their ubiquity are of significant importance in advanced manufacturing and the need to join them together is dramatically increased in recent years.
\end{abstract}


However, joining Al/Al alloys with steels by means of welding techniques has been one of the most challenging works as the joining is complicated due to the great difference in their thermophysical properties which may lead to the formation of Al-rich hard and brittle intermetallic compounds (IMCs). It was reported that the formation of IMCs phases is highly dependent on thermal impacts, such as temperature and holding time, during the joining process. The IMCs layers at the interface adjacent to the steel are generally considered to be the main cause for the mechanical degradation of the joints ${ }^{[1-10]}$. It is of general interest to minimize the thickness of IMC phases at the joint interface by metallurgical methods and/or by the application of low interaction temperatures and short times to limit reaction and interdiffusion.

The research on joining of $\mathrm{Al} / \mathrm{Al}$ alloys with steels is vast but is mainly on the brazing of $\mathrm{Al}$ alloys to stainless steel and focused on the applications in which the material in use is very thin (usually $<1 \mathrm{~mm}$ in thickness). On the other hand, for materials with thicker sections (> $6.0 \mathrm{~mm}$ in thickness) in the shipbuilding industry, the development toward lightweight and fast speed vessels uses a great number of the $\mathrm{Al} /$ steel structural transition joints (STJ) to attach the Al superstructure to the steel hull. By this arrangement, the total weight of the ship is reduced due to the lighter Al superstructure ${ }^{[11]}$. As shown in Figure 1, the typical tri-metallic STJ is a configuration consisted of a steel (ASTM A516) backer plate clad to an Al alloy (AA5586/5083) flyer plate, with pure Al (AA1050) interlayer plate placed between the former two. Currently, commercial STJ is normally produced by explosion welding which is a solid-state joining process that uses explosive force to create an electron sharing metallurgical bond between two metal components and avoids the formation of IMCs. However, the explosion welding involves some difficulties as the joint is not easy to produce and is expensive, dangerous and limited in shape. For these reasons, researchers and manufacturers persistently explore the feasibility of traditional or advanced joining processes to join $\mathrm{Al} /$ steel STJ optimally.

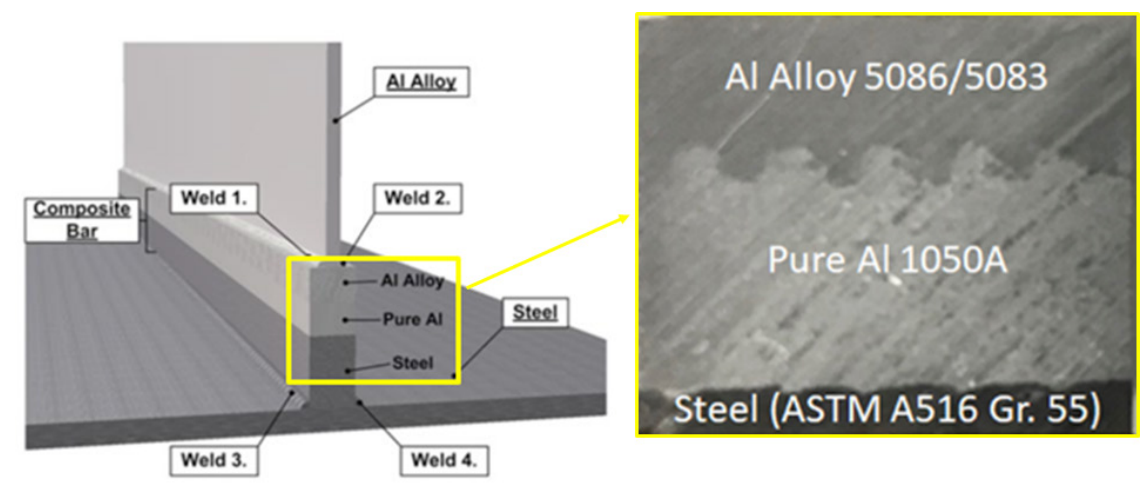

Figure 1. The typical structure of structural transition joints (STJ) ${ }^{[12]}$.

Brazing is a solid-state joining technique at a relatively low process temperature in comparison to fusion welding and one of the potential methods for joining $\mathrm{Al}$ and steel. It provides a metallurgical bonding between the faying surfaces and the filler metal without melting the base metal as well as a possibility in joining of components having complex structure and a significant number of joints in one step. There are various types of brazing processes such as dip brazing, induction brazing, laser brazing, resistance brazing, furnace brazing, and oxyacetylene flame brazing. Up to now, there are a few reports on the brazing of Al alloys to steel/stainless steels by means of furnace brazing, vacuum brazing or even in air using flux for brazing. However, most of reported work were focused on the joining between $\mathrm{Al}$ alloys and stainless steel ${ }^{[1-3,6-10]}$, there is few reports on the brazing of pure $\mathrm{Al}$ to steels ${ }^{[4,5]}$ which is one of the main joints of STJ.

In this work, pure $\mathrm{Al} /$ steel joints are produced by furnace brazing using an Al-12 wt. \% Si filler metal and an Al brazing flux to eliminate the oxide films on both surfaces of pure Al and steel. The mechanical properties of joints are determined by tensile shear strength and micro-hardness tests at ambient. The microstructure of the brazed joints and the fracture 
surfaces of the tensile tested samples are investigated by scanning electron microscopes (SEM), SEM energydispersive X-ray (EDX) and optical microscope (OM). This study aims to address the brazeability between pure Al and steel and to investigate the influence of the brazing conditions on the mechanical properties of the joints.

\section{Experimental Procedures}

The base metals used for this study are AA1050 pure Al and ASTM A516 Grade 55 steel. The filler used is an Al-base filler metal, Al-12 wt. \%Si filler or BA4047 (hereafter expressed with AlSi12) and the flux used is an Al brazing flux TB-500 with mixtures of chlorides and fluorides (manufactured by Tokyobraze Co., Ltd, Japan). The flux is applied to eliminate the oxide films on both surfaces of pure $\mathrm{Al}$ and steel during the brazing process so that the molten filler metal can successfully wet the solid $\mathrm{Al}$ and steel. The chemical compositions of base metals and filler are shown in Table $\mathbf{1 .}$

Table 1. Chemical composition of the used materials.

\begin{tabular}{|c|c|c|c|c|c|c|c|c|c|c|c|c|c|}
\hline \multirow[t]{2}{*}{ Alloy } & \multicolumn{13}{|c|}{ Alloy Composition (wt. \%) } \\
\hline & Al & $\mathbf{F e}$ & $\mathbf{C}$ & $\mathbf{N i}$ & Si & Mn & $\mathrm{Cu}$ & Zn & Mg & $\mathbf{T i}$ & $\mathbf{P b}$ & $\mathbf{P}$ & $\mathbf{S}$ \\
\hline AA1050 & bal. & 0.20 & - & - & 0.07 & 0.12 & 0.006 & 0.004 & 0.002 & 0.016 & - & - & - \\
\hline A516 Gr. 55 & - & bal. & $0.18-0.26$ & - & $0.13-0.45$ & $0.55-1.3$ & - & - & $0.6-1.2$ & - & - & 0.035 & 0.035 \\
\hline AlSi12 & bal. & 0.45 & - & 0.08 & 11.2 & 0.42 & 0.1 & 0.12 & 0.1 & 0.1 & 0.1 & - & - \\
\hline
\end{tabular}

The base metals were supplied as plates and were machined into the plates with a size of $36(\mathrm{~L}) \times 11$ $(\mathrm{W}) \times 6(\mathrm{~T}) \mathrm{mm}^{3}$ which is suitable for tensile shear strength testing. They were polished on the faying surfaces by 800 grit silicon carbide paper to remove the surface oxide and cleansed to degrease in acetone by an ultrasonic cleaner. Due to a clean, oxide free faying surface is generally required in order to get the molten filler metal successfully wet the $\mathrm{Al}$ and steel, the Al brazing flux TB-500 powder was uniformly pasted on the faying surfaces of the base metals to be brazed. A lap joint with around $8 \mathrm{~mm}$ overlap was configured in this study. As schematically shown in Figure 2, the
AlSi12 filler wire (1.2 $\mathrm{mm}$ in diameter) was cut into $10 \mathrm{~mm}$ in length and placed along the seam of the joint along with flux powder. A ceramic block was used as a brazing load to hold the parts together in order to keep the clearance between the faying surfaces constant and then the good wettability and flow of molten filler by the capillary force. It needs to indicate that the lap join was duplicated and assembled in parallel under the same load during the brazing. The double joining configuration allows tensile shear strength testing and microstructure analysis on the samples with nearly the same brazing conditions.

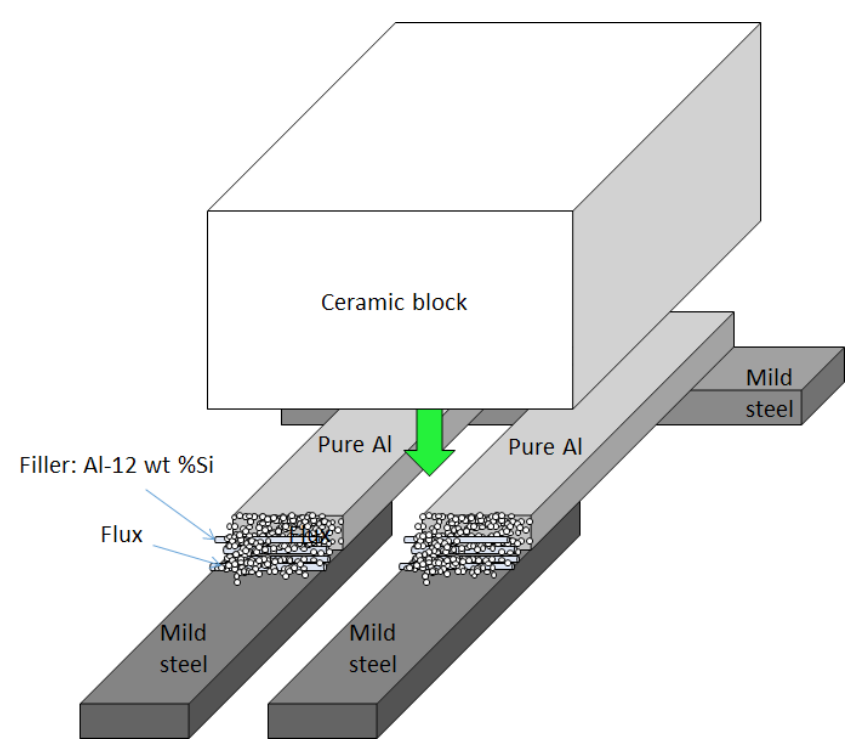

Figure 2. Schematic diagram of the brazing assembly. 
The whole assembly was then placed in a ceramic tray and inserted into the middle of a horizontal quartz tube furnace (Elite, Germany). The Al/steel joints were brazed at a setting temperature of $630{ }^{\circ} \mathrm{C}$. The heating process with a heating rate of $10{ }^{\circ} \mathrm{C} / \mathrm{min}$ and the brazing process with a holding time of 5, 10, 15, and $30 \mathrm{~min}$ were carried out in a continually back-filled Argon (Ar) gas atmosphere. The typical time-temperature brazing profile is shown in Figure 3. It needs to indicate that the brazing temperature set for the brazing processing is the value measured by a $\mathrm{K}$ type thermocouple, attached on the quartz wall of the tube furnace and located slightly above the brazing assembly. After calibration with temp tab, the real brazing temperature around faying surface of joints is about $600-605{ }^{\circ} \mathrm{C}$. The temperatures used for the brazing profiles and discussions hereafter will be the values after calibrations. The cooling process with a cooling rate of $10^{\circ} \mathrm{C} / \mathrm{min}$ was performed in an Ar atmosphere as well. Considering the harsh temperature in the real application and its potential impact on the growth of IMC layers, additional thermal exposures at $480{ }^{\circ} \mathrm{C}$ for $30 \mathrm{~min}$ were performed after brazing processing.

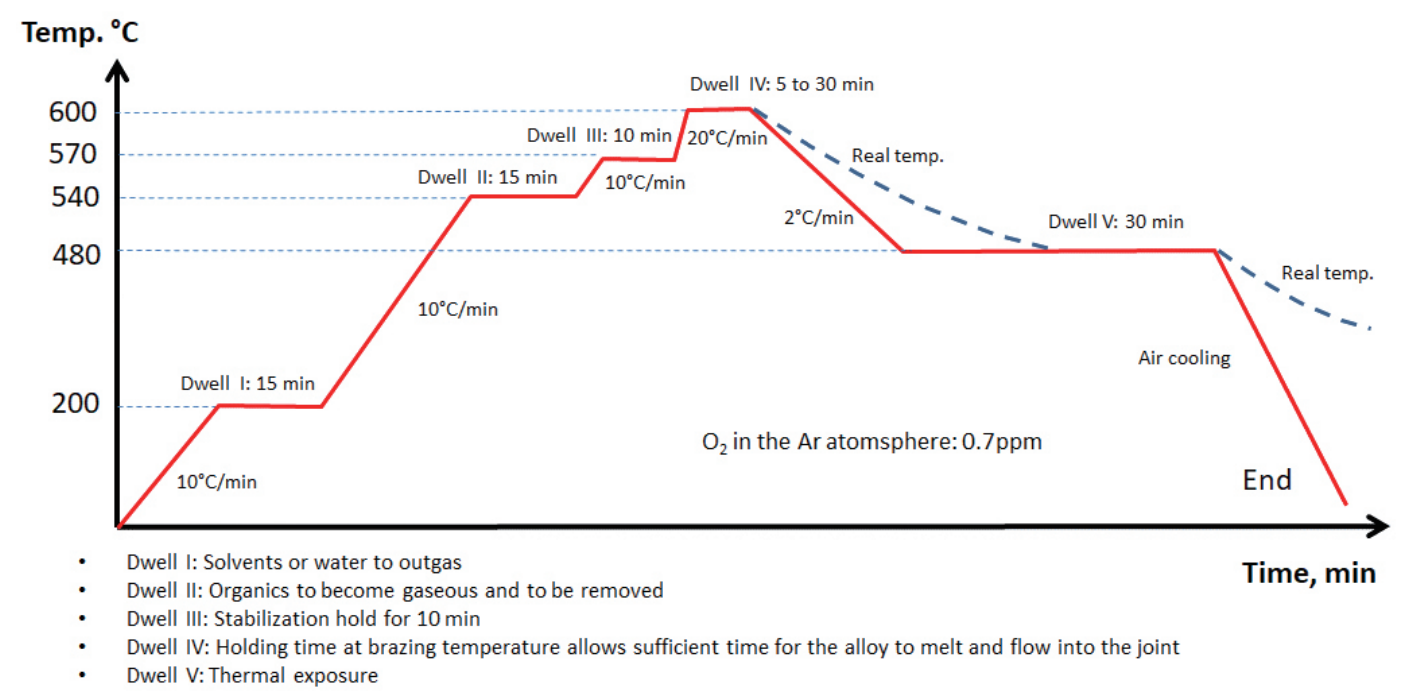

Figure 3. Time-temperature brazing profile for furnace brazing cycle.

Cross sections of the brazed samples and residuals on the Al fracture surface were prepared by metallurgical grinding and polishing in order to investigate the microstructure and to check the formation of the defects after the brazing process. Microstructural analyses were performed using Zeiss Ultra Plus FE-SEM (Carl Zeiss Microscopy GmbH, Germany). The chemical composition of the microstructures was analysed by EDX spectroscopy attached with the SEM. Tensile shear strength tests were carried out using a INSTRON 5982 tensile tester (INSTRON, USA) with a load cell $100 \mathrm{kN}$ and side action grips attached for lap joint testing, and performed at a constant cross-head speed of $1 \mathrm{~mm} / \mathrm{min}$. The hardness of different layers in the joint seam was assessed by using Matsuzawa Vickers hardness machine with a load of 0.05 $\mathrm{Kg}$ force, hereafter expressed by HV (0.05).

\section{Results and Discussions}

\subsection{Microstructure Investigations}

Figure 4a shows a typical OM micrograph of the $\mathrm{Al} /$ steel brazed joints. The microstructure in the imagecan be roughly featured into four zones: pure Al, solidified brazing alloy, reaction layer and steel. Among them, the reaction layer, which is the most attractive zone in the study, is amplified in more detail in the SEM micrographs, as shown in Figure 4b. Three layers can be further observed at the interface between steel and solidified brazing alloy in Figure $\mathbf{4 b}$. The layers are expressed with the $1^{\text {st }} \mathrm{IMC}$, intermediate, and the $2^{\text {nd }} \mathrm{IMC}$ layers for easier descriptions hereafter. It can be found that in the $2^{\text {nd }}$ IMC layer, a variable quantity of visible cracks and pores are distributed in a specific zone which is directly adjacent to the interface between reaction layer and steel. Figure 5a-d exhibits the point element analyses by using SEM-EDX. The selected points in different layers are shown in Figure 5a-c, and a SEM image marked with chemical composition distribution in each layer is shown in Figure 5d. 

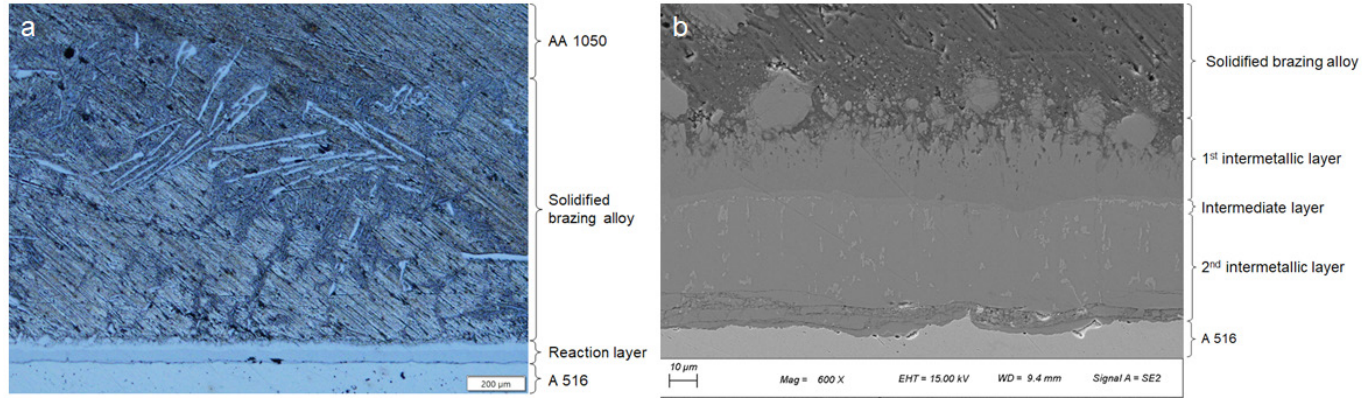

Figure 4. (a) OM micrograph of the Al/steel brazed joint; (b) SEM micrograph of the reaction layer in the joint.
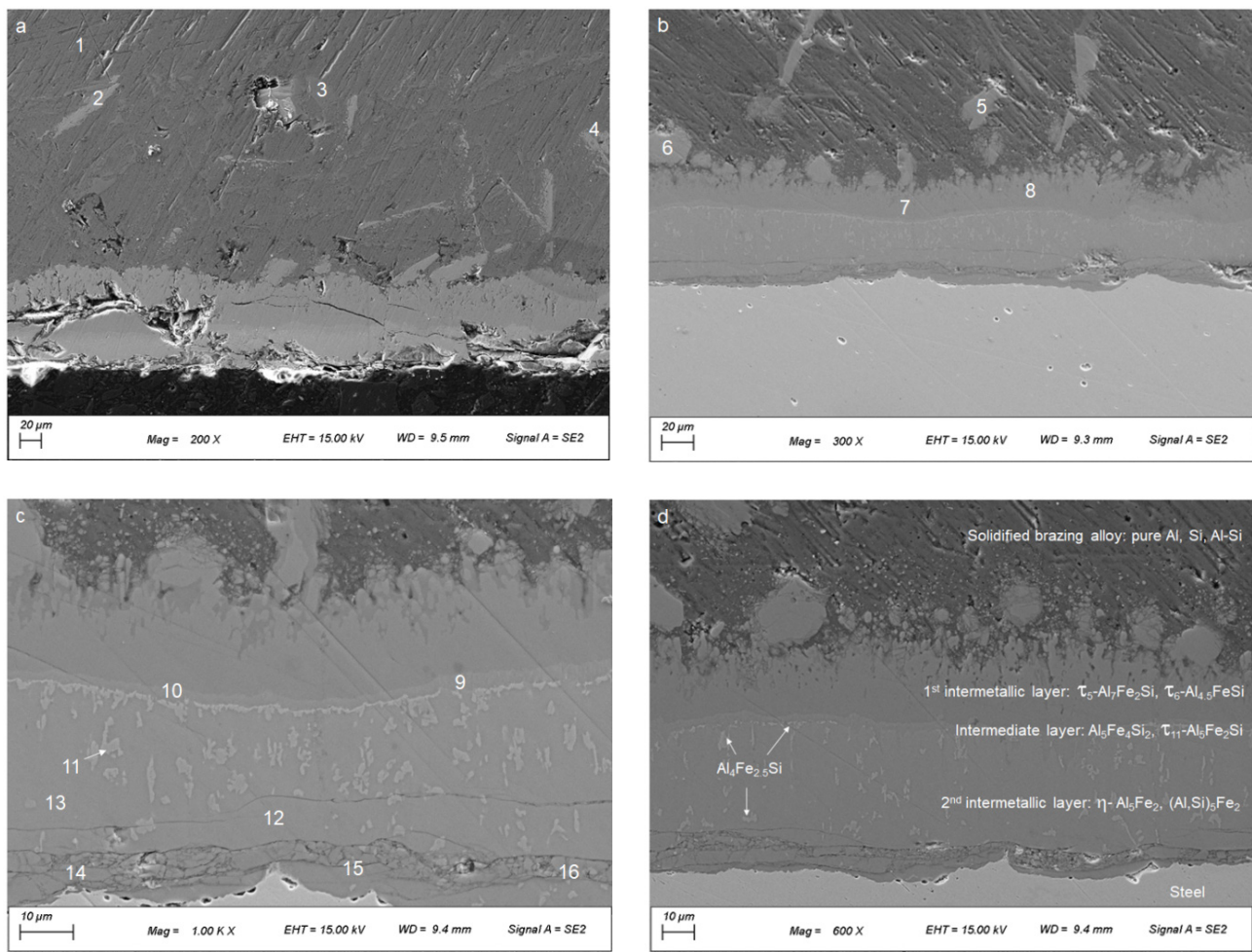

Figure 5. Elements analysis on the joint with holding time of $30 \mathrm{~min} /$ with thermal exposure by using SEM-EDX at the points in (a) solidified brazing alloy zone (fracture surface at Al side); (b) $1^{\text {st }}$ IMC layer; (c) intermediate and the $2^{\text {nd }}$ IMC layers; (d) SEM image marked with possible phases around different layers.

Table 2. SEM-EDX analysis results on the joint with holding time of $30 \mathrm{~min} /$ with thermal exposure.

\begin{tabular}{|c|c|c|c|c|c|}
\hline \multirow{2}{*}{\multicolumn{2}{|c|}{ Selected region }} & \multicolumn{3}{|c|}{ Element ratio (at. \%) } & \multirow{2}{*}{ Possible phase } \\
\hline & & Al & $\mathrm{Fe}$ & $\mathbf{S i}$ & \\
\hline \multirow{4}{*}{$\begin{array}{l}\text { Solidified } \\
\text { brazing alloy } \\
\text { zone }\end{array}$} & 1 & 100.00 & - & - & $\mathrm{Al}$ \\
\hline & 2 & 66.30 & 15.56 & 18.14 & $\tau_{6}-\mathrm{Al}_{4.5} \mathrm{FeSi}$ \\
\hline & 3 & 0.90 & - & 99.10 & $\mathrm{Si}$ \\
\hline & 4 & 87.18 & - & 12.82 & AISi $_{12}$ \\
\hline \multirow{4}{*}{$1^{\text {st IMC layer }}$} & 5 & 66.22 & 15.99 & 17.79 & $\tau_{6}-\mathrm{Al}_{4.5} \mathrm{FeSi}$ \\
\hline & 6 & 69.63 & 19.87 & 10.51 & $\tau_{5}-\mathrm{Al}_{7} \mathrm{Fe}_{2} \mathrm{Si}$ \\
\hline & 7 & 68.05 & 20.19 & 11.75 & $\tau_{5}-\mathrm{Al}_{7} \mathrm{Fe}_{2} \mathrm{Si}$ \\
\hline & 8 & 68.14 & 20.10 & 11.76 & $\tau_{5}-\mathrm{Al}_{7} \mathrm{Fe}_{2} \mathrm{Si}$ \\
\hline \multirow{8}{*}{$\begin{array}{l}\text { Intermediate } \\
\text { and the } 2^{\text {nd }} \\
\text { IMC layers }\end{array}$} & 9 & 45.09 & 35.16 & 19.75 & $\mathrm{Al}_{5} \mathrm{Fe}_{4} \mathrm{Si}_{2}$ \\
\hline & 10 & 62.52 & 25.25 & 12.23 & $\tau_{11}-\mathrm{Al}_{5} \mathrm{Fe}_{2} \mathrm{Si}$ \\
\hline & 11 & 52.07 & 34.31 & 13.62 & $\mathrm{Al}_{4} \mathrm{Fe}_{2.5} \mathrm{Si}$ \\
\hline & 12 & 69.66 & 28.96 & 1.38 & $\eta-(\mathrm{Al}, \mathrm{Si})_{5} \mathrm{Fe}_{2}$ \\
\hline & 13 & 70.97 & 27.59 & 1.44 & $\eta-(\mathrm{Al}, \mathrm{Si})_{5} \mathrm{Fe}_{2}$ \\
\hline & 14 & 70.32 & 28.19 & 1.48 & $\eta-(\mathrm{Al}, \mathrm{Si})_{5} \mathrm{Fe}_{2}$ \\
\hline & 15 & 70.44 & 28.17 & 1.39 & $\eta-(\mathrm{Al}, \mathrm{Si})_{5} \mathrm{Fe}_{2}$ \\
\hline & 16 & 71.59 & 27.33 & 1.09 & $\eta-(\mathrm{Al}, \mathrm{Si})_{5} \mathrm{Fe}_{2}$ \\
\hline
\end{tabular}


The stoichiometry of possible intermetallic phases is identified approximately according to the elements at. $\%$ and Al-Fe binary/Al-Fe-Si ternary phase diagram at $600{ }^{\circ} \mathrm{C}$, as shown in Table 2. The similar element distributions were observed on both full cross-section samples for microstructure analysis and fracture surface with residual reaction zone samples for $5 \mathrm{~min}$,
$10 \mathrm{~min}$, and $15 \mathrm{~min}$ holding times. Figure 6 shows an exemplary SEM micrograph of the reaction layers after 30 min holding time and its corresponding EDX line-scan on the element distributions. A yellow line in the Figure 6a is used as a reference line along which chemical compositions were measured by EDX. The corresponding results are presented in Figure $6 \mathbf{b}$.

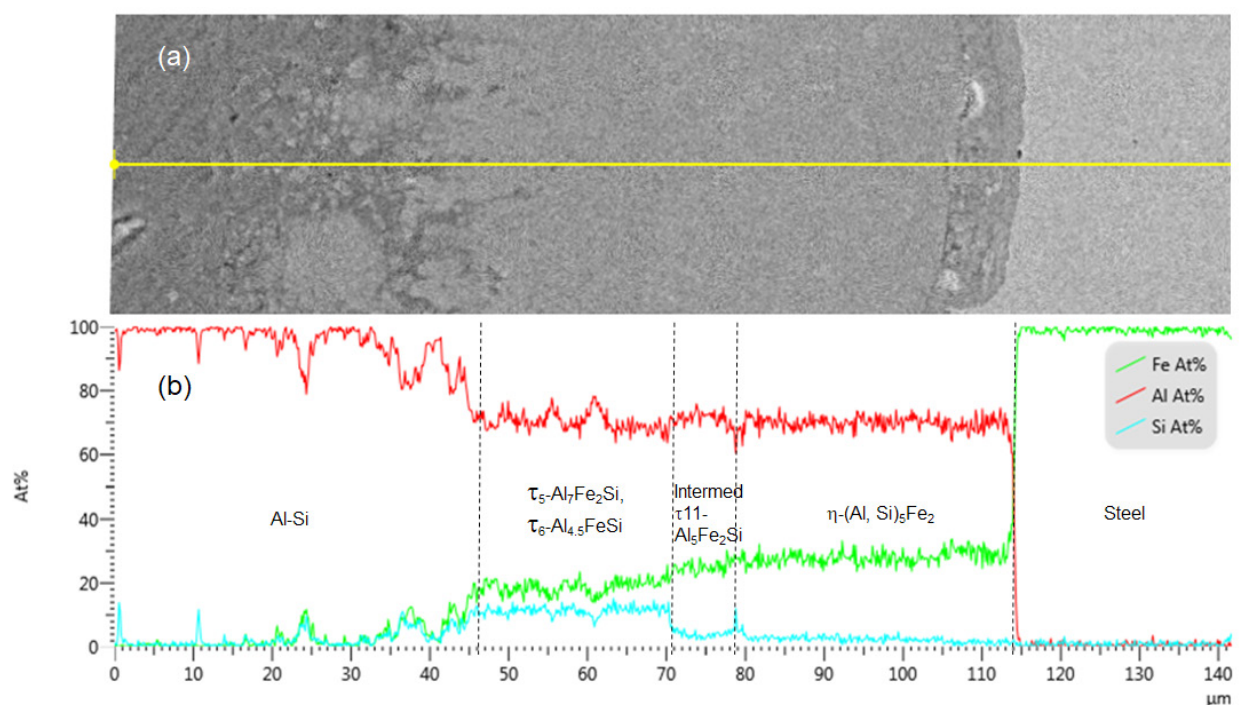

Figure 6. (a) SEM micrograph. (b) SEM-EDX line scan result measured along the yellow line in (a).

In general, the solidified brazing alloy consists of a primary Al solid solution, an Al-Si eutectic and Al-Fe-Si precipitates $\left(\tau_{6}\right)$ which are formed due to the diffusion of $\mathrm{Fe}$ into the brazing metal. The chemical composition of the $1^{\text {st }}$ IMC layer or the reaction layer adjacent to the solidified brazing alloy corresponds to the $\tau_{5}$ phase, whereas the result for the $2^{\text {nd }}$ IMC layer or the reaction layer adjacent to the steel suggests the presence of $\eta$ phase with small amounts of $\mathrm{Si}$ in solid solution (1-1.5 at. \%). The intermediate layer consists of a multiphase structure with some simplified phases, such as $\tau_{11}-\mathrm{Al}_{5} \mathrm{Fe}_{2} \mathrm{Si}$. However, the intermediate layer shows strong local variations in composition that could not be reliably identified by the EDX. Interestingly, it can also be observed a specific zone in the $2^{\text {nd }}$ IMC layer which is directly adjacent to the interface between reaction layer and steel displays a lot of cracks and pores, the similar zones can be observed from all other samples in the same layer. Additionally, as shown in Figure 5c-d, some fine-scale features (white particles) sporadically distributed in the $\eta$ phase layer and aggregated along the interface between $\eta$ and intermediate layer can be observed. The features were
EDX analysed to be Si-rich compound, most probably consisting of $\mathrm{Al}_{4} \mathrm{Fe}_{2.5} \mathrm{Si}$ or mostly close to $\tau_{10}$ phase.

\subsection{Tensile Shear Strength Test}

To evaluate the mechanical properties of the joints, tensile shear strength tests were performed using a INSTRON 5982 tensile tester (INSTRON, USA) with a load cell $100 \mathrm{kN}$ and side action grips attached for lap joint testing, and performed at a constant crosshead speed of $1 \mathrm{~mm} / \mathrm{min}$. Figure 7 shows the results of the tensile shear strength tests of the brazed samples at different conditions. It can be found that the shear strength of brazed joints exhibits some scatter but with an approximate dependence of average strength on the holding time: it reaches to the highest which is approximately around $23 \mathrm{MPa}$ for the joint with the holding time of $10 \mathrm{~min}$, and remains nearly constant or a bit decrease with the increase of holding time. The comparison between the joints for 30 min holding time with or without $30 \mathrm{~min}$ thermal exposure indicates few differences in shear strength, which means that additional $30 \mathrm{~min}$ exposure at $480{ }^{\circ} \mathrm{C}$ is not sufficient to induce the deterioration of the joints. However, the 
shear strength for joint with holding time of $5 \mathrm{~min}$ which is the shortest holding time in this study exhibits a low value that is quite confusing and has been reported by Roulin et al. ${ }^{[1]}$ and Abood et al. ${ }^{[8]}$. The mechanism behind for the decrease in shear strength at short holding times, especially less than $10 \mathrm{~min}$, is not well explained so far. Furthermore, the shear strength values measured in this study are roughly matching with the results of Roulin et al. ${ }^{[1]}$ which is shown in Figure 7 as well for the comparison, Winiowski (18-23 $\mathrm{MPa})^{[3]}$ and Fedorov et al. $(\sim 22 \mathrm{MPa})^{[6]}$.

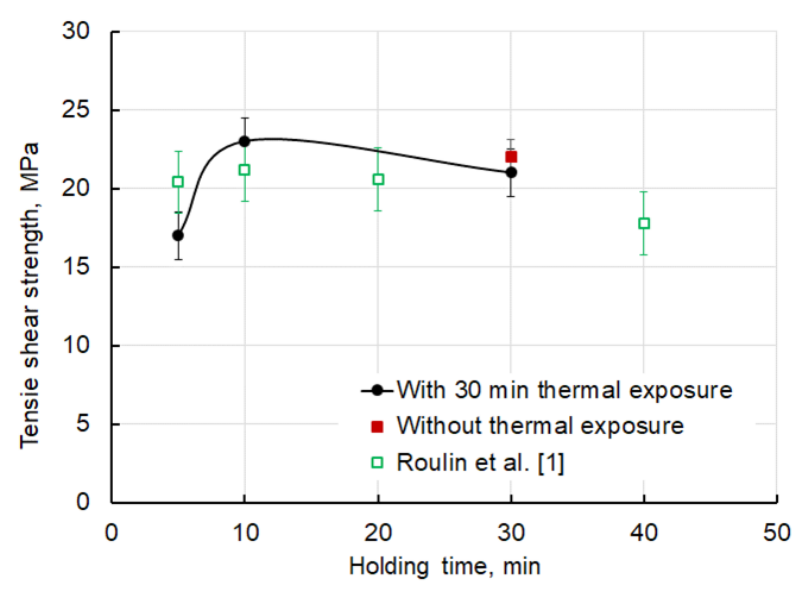

Figure 7. Tensile shear strength vs. holding time.

It needs to indicate that the strength of joint for holding time $15 \mathrm{~min}$ is around $6 \mathrm{MPa}$ and not displayed in the Figure 7 because the joint is obviously unsuccessful. When compared its fracture surface and as-brazed surface, as shown in Figure 8a-b, it can be observed that a specific layer adjacent to the steel was formed in the $\eta$ phase. The layer is around

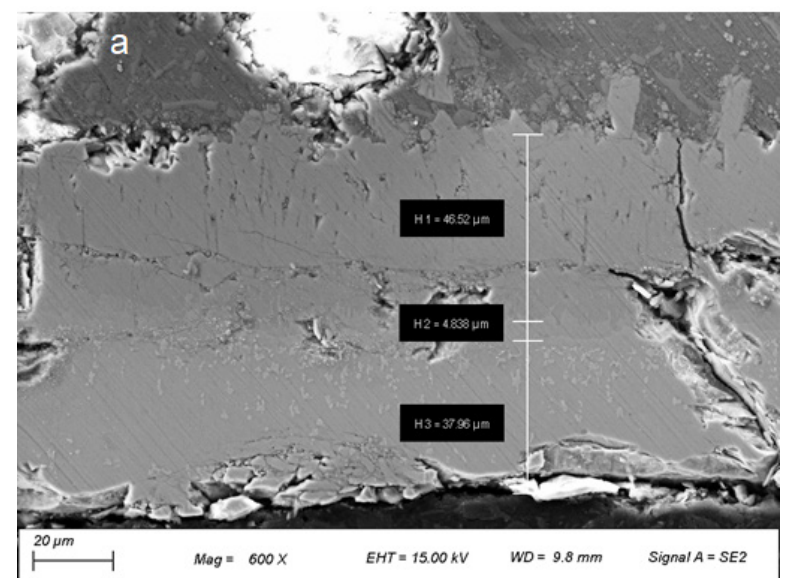

$25 \mu \mathrm{m}$ in thickness and obviously different from the rest of $\eta$ phase. The EDX element analysis, as shown in the Figure 9, indicates that this layer was heavily oxidized. The possible reasons are the oxide film on the faying surface of steel was not completely eliminated before the brazing process or the lack of flux during the brazing process.

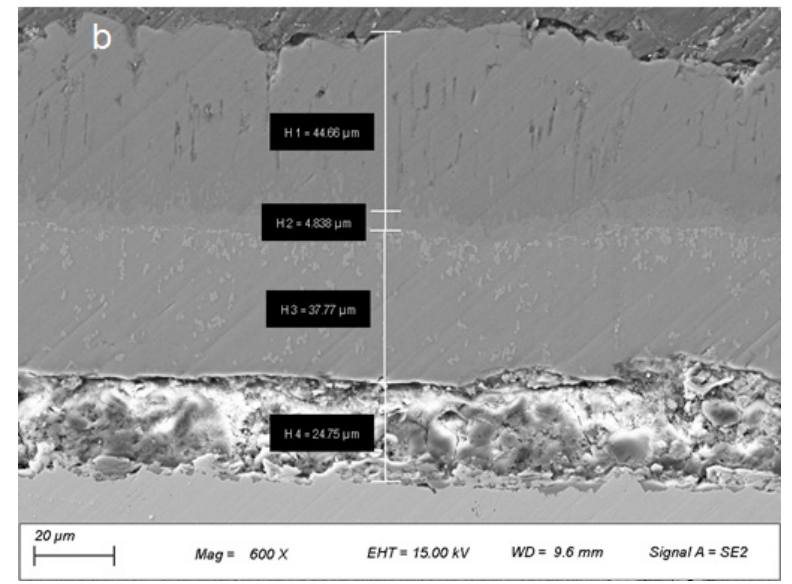

Figure 8. SEM micrograph of the joint at holding time of 15 min with thermal exposure. (a) residual on the Al fracture surface. (b) full cross-section of the joint seam.

Interestingly, a specific zone directly adjacent to the interface between $\eta$ layer and steel can be found in the rest samples with different holding times. The specific zone is filled with a lot of visible pores and cracks, but not heavily oxidized as that in the joint at holding time of $15 \mathrm{~min}$. Figure 10a-b shows the exemplary fracture and as-brazed surfaces of brazed joint at holding time of $30 \mathrm{~min}$. It can be found the specific zone is around 8 to $10 \mu \mathrm{m}$ in thickness and has a lot of pores and cracks. The sample was fractured within the $\eta$ phases obviously and the fracture happened at the area 28$35 \mu \mathrm{m}$ away from the intermediate layer. Similarly, 
the fractures can be observed in the $\eta$ phases for the

samples with holding time of $5 \mathrm{~min}$ and $10 \mathrm{~min}$ as well.
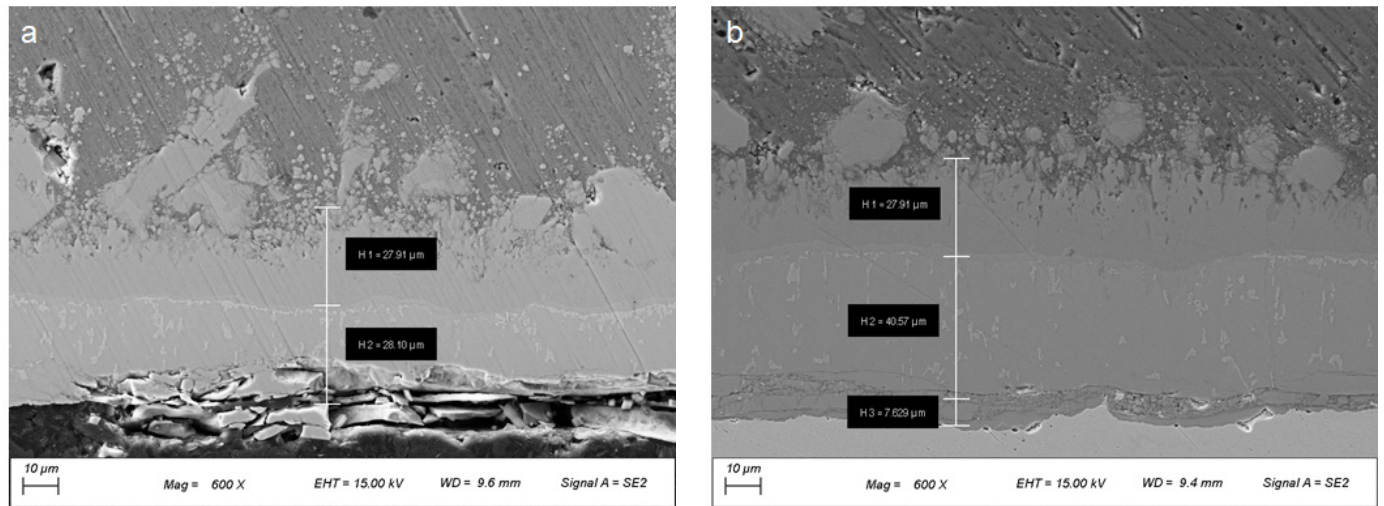

Figure 9. Heavily oxidized zone of the joint at holding time of 15 min with thermal exposure. (a) SEM micrograph. (b)

SEM-EDX line scan result measured along the yellow line in (a).

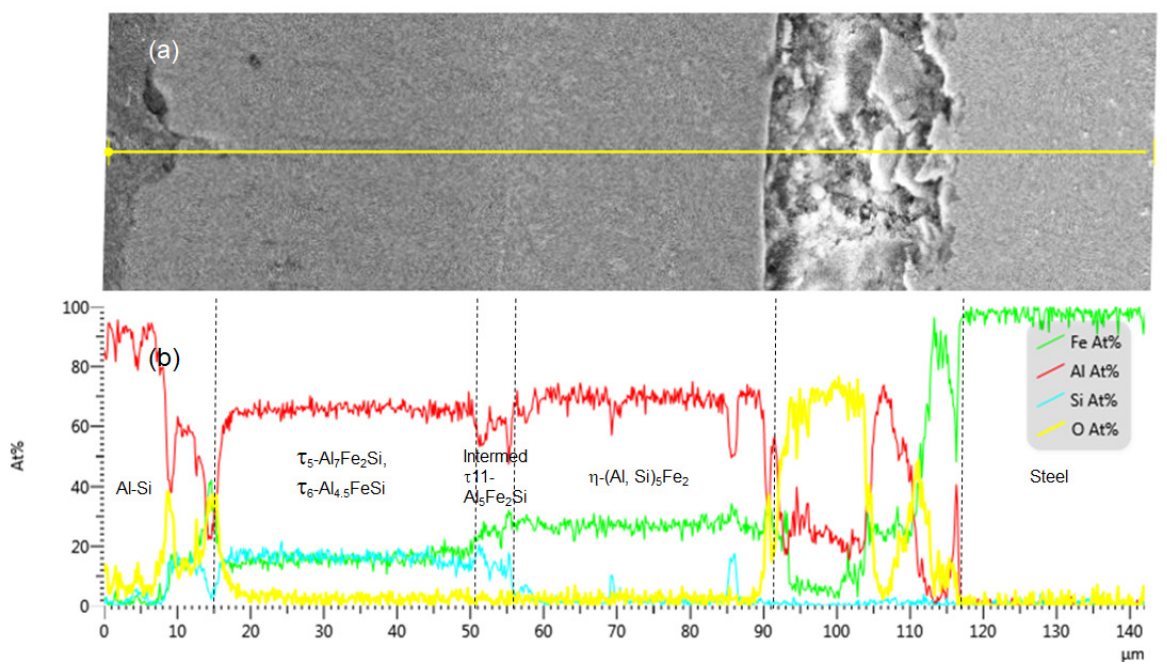

Figure 10. SEM micrograph of the joint at holding time of 30 min with thermal exposure. (a) residual on the Al fracture surface. (b) full cross-section of the joint seam.

Table 3. Summary of layer thickness and tensile shear strength for joints at different conditions.

\begin{tabular}{|c|c|c|c|c|c|c|c|c|}
\hline \multirow{3}{*}{$\begin{array}{l}\text { Holding } \\
\text { time }{ }^{1)} \text {, } \\
\text { min }\end{array}$} & \multirow{3}{*}{$\begin{array}{c}\text { Thermal } \\
\text { exposur } \\
\text { e time }{ }^{2)} \text {, } \\
\text { min }\end{array}$} & \multicolumn{6}{|c|}{ Layer thickness , $\mu \mathrm{m}$ (approx.) } & \multirow{3}{*}{$\begin{array}{c}\text { Tensile } \\
\text { shear } \\
\text { strength, } \\
\mathrm{MPa}\end{array}$} \\
\hline & & \multirow{2}{*}{$\begin{array}{c}\text { Solidified } \\
\text { brazing } \\
\text { alloy }\end{array}$} & \multirow{2}{*}{$\begin{array}{c}1^{\text {st }} \text { IMC } \\
\text { layer, } \tau_{5}\end{array}$} & \multirow{2}{*}{$\begin{array}{c}\text { Intermediate } \\
\text { layer }\end{array}$} & \multicolumn{2}{|c|}{$2^{\text {nd }}$ IMC layer, $\eta$} & \multirow{2}{*}{$\begin{array}{l}\text { Total reaction } \\
\text { - layer }\left(\tau_{5}\right. \\
\text { +intermed }+\eta) \\
\end{array}$} & \\
\hline & & & & & $\begin{array}{c}\text { Full } \\
\text { layer }\end{array}$ & $\begin{array}{l}\text { Residual } \\
\text { on the Al } \\
\text { fracture } \\
\text { surface } \\
\end{array}$ & & \\
\hline 5 & 30 & $190-200$ & 41 & 7 & 48 & 38 & 96 & 17 \\
\hline 10 & 30 & $160-210$ & 45 & 4.5 & 25 & 15 & 75 & 23 \\
\hline $15^{3)}$ & 30 & $178-210$ & 50 & 4.8 & $63 / 48^{5)}$ & 38 & 103 & 6 \\
\hline 30 & 30 & 750 & 28 & 2.7 & 45 & 35 & 76 & 21 \\
\hline 30 4) & 0 & 370 & 29 & 2.5 & 41 & 31 & 73 & 22 \\
\hline
\end{tabular}

1) Holding time of joints exposed to brazing temperature of $605 \pm 5^{\circ} \mathrm{C}$.

2) Holding time of joints exposed to temperature of $480 \pm 5^{\circ} \mathrm{C}$.

3) The oxide layer was not thoroughly removed from the steel surface in the sample preparation or lack of flux which led to the thicker layer with defects and oxides during brazing.

4) A sample with same conditions as that with 30 min holding time, but without thermal exposure at $480 \pm 5^{\circ} \mathrm{C}$. Using zero for its thermal exposure time.

5) Estimated by assuming $10 \mu \mathrm{m}$ as an average thickness of the specific zone. 
Table 3 shows a summary of layer thickness and tensile shear strength for joints at different conditions. In general, the thickness of solidified brazing alloy increases with the increase of holding time. The thickness of the $1^{\text {st }}$ IMC layer which mainly consists of $\tau_{5}$ phase is directly proportional to the holding time until $15 \mathrm{~min}$, and then becomes inversely proportional. The thickness of the $2^{\text {nd }}$ IMC layer which mainly consists of $\eta$ phase is inversely proportional to the shorter holding time and then becomes directly proportional longer holding time. The tensile shear strength of joints is inversely proportional to the thickness of the $2^{\text {nd }}$ IMC layer ( $\eta$ phase) and particularly governed by a specific zone which is located in the $2^{\text {nd }}$ IMC layer, directly adjacent to the interface between reaction layer and steel and distributed with a lot of visible pores and cracks. All the interfacial failure in joints happens as cleavage within this specific zone in the $2^{\text {nd }}$ IMC layer. Furthermore, by the comparison between the joints for $30 \mathrm{~min}$ holding time with or without $30 \mathrm{~min}$ thermal exposure, few differences in the thickness of each IMC layer can be found. The thickness of solidified brazing alloy, however, has a double increase with the thermal exposure. The total thickness of reaction layer at different holding times, except $15 \mathrm{~min}$, exhibits some scatter values together with nearly no dependence of square root of holding times, which means the growth of the IMC layers is not exactly followed the parabolic kinetics. The relatively short holding times or limited sampling points in this study are the possible reasons behind.

\subsection{Micro-hardness of Brazed Samples}

The Vickers hardness of base metals, solidified brazing alloy and different IMC layers was investigated in this study. Figure 11 a-b shows the OM image with micro-indentations and the corresponding hardness distribution across the joint seam for the sample brazed with 30 min holding time. It can be observed that within the reaction zone, a gradual increase of hardness from $650 \mathrm{HV}(0.05)$ in the $1^{\text {st }}$ IMC layer ( $\tau_{5}$ phase) to the highest values of $1050 \mathrm{HV}(0.05)$ measured in the $2^{\text {nd }}$ IMC layer ( $\eta$ phase) adjacent to steel. The results of hardness measurements for the samples brazed with different holding time are listed in the Table 4.
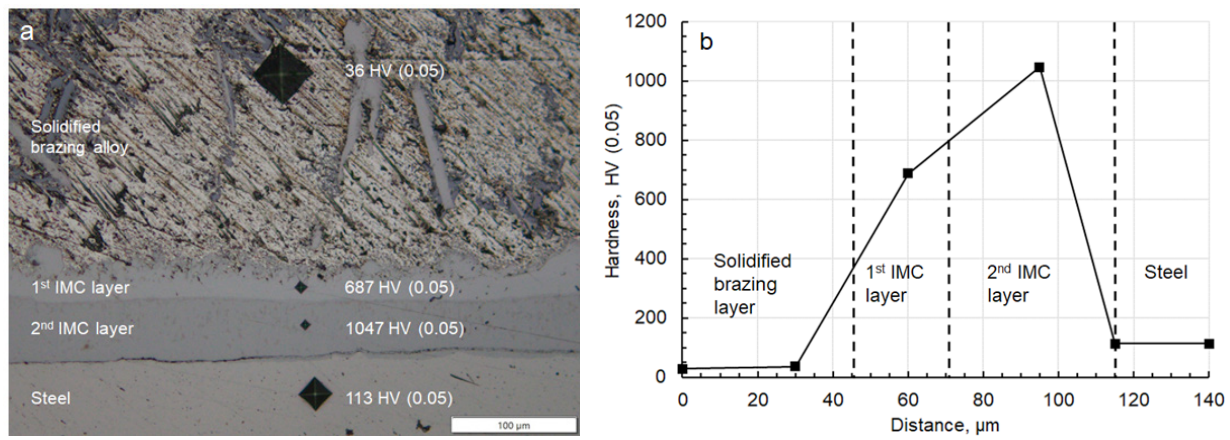

Figure 11. (a) OM image with micro-indentations at different layers, and (b) hardness along the distance from Al to steel, for the sample brazed with 30 min holding time/with thermal exposure.

Table 4. Hardness of different layers in the reaction zone for the sample brazed with different conditions.

\begin{tabular}{|c|c|c|c|c|}
\hline \multirow{2}{*}{$\begin{array}{l}\text { Holding } \\
\text { time 1), min }\end{array}$} & \multirow{2}{*}{$\begin{array}{c}\text { Thermal } \\
\text { exposure time }{ }^{2)} \text {, } \\
\text { min }\end{array}$} & \multicolumn{3}{|c|}{ Vickers hardness, HV (load: $0.05 \mathrm{Kg}$ ) } \\
\hline & & $\begin{array}{c}\text { Solidified brazing } \\
\text { alloy }\end{array}$ & $1^{\text {st }}$ IMC layer, $\tau_{5}$ & $2^{\text {nd }}$ IMC layer, $\eta$ \\
\hline 5 & 30 & 35 & 427 & 639 \\
\hline 10 & 30 & 35 & 424 & 948 \\
\hline $15^{3)}$ & 30 & 31 & 530 & 968 \\
\hline 30 & 30 & 36 & 687 & 1047 \\
\hline 30 4) & 0 & 86 & 802 & 755 \\
\hline
\end{tabular}

1) Holding time of joints exposed to brazing temperature of $605 \pm 5^{\circ} \mathrm{C}$.

2) Holding time of joints exposed to temperature of $480 \pm 5^{\circ} \mathrm{C}$.

3) The oxide layer was not thoroughly removed from the steel surface in the sample preparation or lack of flux which led to the thicker layer with defects and oxides during brazing.

4) A sample with same conditions as that with 30 min holding time, but without thermal exposure at $480 \pm 5^{\circ} \mathrm{C}$. Here using zero for its thermal exposure time. 
In general, with the increase of holding time, the hardness of base metals is slightly decreased, from 34 $\mathrm{HV}(0.05)$ to $28 \mathrm{HV}(0.05)$ for $\mathrm{Al}$ and $190 \mathrm{HV}(0.05)$ to $113 \mathrm{HV}(0.05)$ for steel. The correlations between the hardness of different layers in the reaction zone and holding time are shown in Figure 12. It can be observed that the hardness of solidified brazing alloy has no significant changes at different holding times. The hardness of $1^{\text {st }} \mathrm{IMC}$ and $2^{\text {nd }}$ IMC layers increases with the increase of holding time. The hardness of $2^{\text {nd }}$ IMC layer exhibits the highest value at each holding time. The higher hardness value in the $2^{\text {nd }} \mathrm{IMC}$ layer is resulted from $\eta$ phase which is mainly consists of $\mathrm{Al}_{5} \mathrm{Fe}_{2}$ compounds with small amounts of $\mathrm{Si}$ in solid solution (1-1.5 at.\%) and has an average hardness range from 1000 to $1158 \mathrm{HV}^{[13]}$. The formation of $\mathrm{Al}-$ $\mathrm{Fe}-\mathrm{Si}$ leads to the relatively lower hardness in the $1^{\text {st }}$ IMC layer. Due to the heat input during the brazing process, thermal induced stresses generate in the zone closely adjacent to the steel as the great differences of hardness exist between the $2^{\text {nd }}$ IMC layer and steel which has around $150 \mathrm{HV}(0.05)$ in this study. As shown in the Figure 10b, the stresses induce the crack initiation in the specific zone, and finally result in the failure of brazed joints. Interestingly, it can be found the hardness in different IMC layers for the sample brazed with 30 min holding time only is approximately the same (red unfilled square and green unfilled diamond). After a $30 \mathrm{~min}$ extra thermal exposure, however, the hardness of the $1^{\text {st }}$ IMC layer $\left(\tau_{5}\right.$ phase $)$ decreases from $800 \mathrm{HV}(0.05)$ to $687 \mathrm{HV}(0.05)$ while the hardness of the $2^{\text {nd }}$ IMC layer ( $\eta$ phase) increases dramatically from $755 \mathrm{HV}(0.05)$ to $1047 \mathrm{HV}(0.05)$.

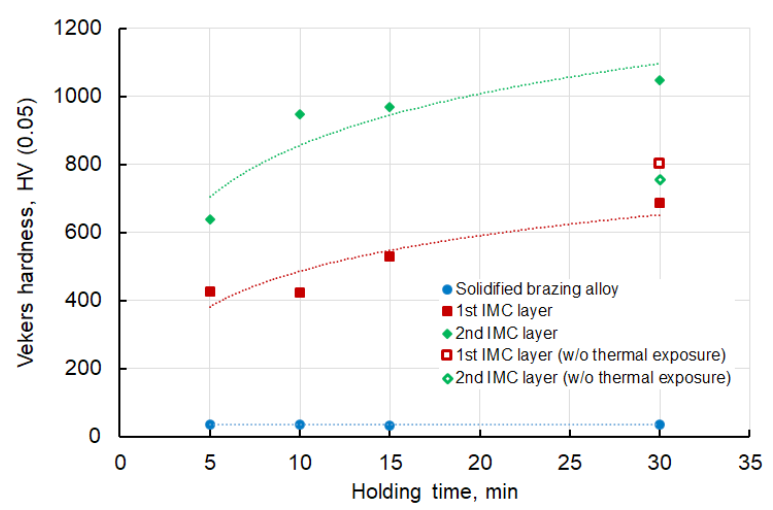

Figure 12. The hardness of different layers in the reaction zone vs. holding times.

\section{Conclusions}

Brazing of pure $\mathrm{Al}$ to steel using an AlSi12 filler metal and an Al brazing flux was carried out in furnace filled with protective atmosphere. Microstructure characterizations of the full/fractured surface of the joints, tensile shear strength and micro-hardness tests were performed on the samples with holding time from 5-30 min at brazing temperature of $600{ }^{\circ} \mathrm{C}$ and additional thermal exposure of $30 \mathrm{~min}$ at temperature of $480{ }^{\circ} \mathrm{C}$. Several conclusions are drawn from the investigation:

- The joint seam for all samples features roughly into four layers. The top layer adjacent to $\mathrm{Al}$ is the solidified brazing alloy layer of which the thickness increases with the increase of holding time. Directly adjacent to the solidified brazing alloy layer is sporadically distributed with $\tau_{6}$ phase and then the $1^{\text {st }}$ IMC layer which is continually distributed with $\tau_{5}$ phase. The thickness of the $1^{\text {st }}$ IMC layer is directly proportional to the holding time until $15 \mathrm{~min}$, and then becomes inversely proportional. The layer directly adjacent to steel is the $2^{\text {nd }}$ IMC layer dominantly distributed with $\eta$ phase and sporadically distributed with white particles which were found to be Si-rich, most probably close to $\tau_{10}$ phase. The thickness of the $2^{\text {nd }}$ IMC layer is inversely proportional to the short holding time and then becomes directly proportional longer holding time. In between the $1^{\text {st }}$ and the $2^{\text {nd }}$ IMC layers, an intermediate layer can be observed for all samples. The intermediate layer is very thin and consists of a multiphase structure that could not be reliably identified.

- The tensile shear strength of joints is inversely proportional to the thickness of the $2^{\text {nd }}$ IMC layer ( $\eta$ phase) and particularly governed by a specific zone which is located in the $2^{\text {nd }}$ IMC layer, directly adjacent to the interface between reaction layer and steel and scattered with a lot of visible pores and cracks. All the interfacial failure in joints happens as cleavage within this specific zone.

- Micro-hardness tests show the hardness of the $2^{\text {nd }}$ IMC remains the highest for all samples and increases with the increase of holding time. The higher hardness in the $2^{\text {nd }}$ IMC layer is resulted from $\eta$ phase which is mainly consists of $\mathrm{Al}_{5} \mathrm{Fe}_{2}$ compounds with small amounts of $\mathrm{Si}$ in solid solution (1-1.5 at. \%) and leads to the limited plasticity or more fragile of this 
phase, resulting in shear bands cutting $\eta$ into blocks rather than deforming it homogeneously. Furthermore, great differences of hardness exist between the $2^{\text {nd }}$ IMC layer and steel also may generate great stresses that induce the crack initiation in the specific zone and finally result in the failure of brazed joints.

\section{References}

[1]. Roulin, M.; Luster, J. W. Strength and Structure of Furnace-Brazed Joints between Aluminum and Stainless Steel. Welding research 1999, 151-s-155-s.

[2]. Liu, S.; Suzumura, A.; Ikeshoji, T.-T.; Yamazaki, T. Brazing of Stainless Steel to Various Aluminum Alloys in Air. JSME Int. J., Ser. A 2005, 48 (4), 420-425. https://doi.org/10.1299/jsmea.48.420.

[3]. Winiowski, A. Structural and Mechanical Propertoes of Brazed Joints of Stainless Steel and Aluminum. Archives of metallurgy and materials 2009, 54 (2), 11.

[4]. Springer, H.; Kostka, A.; Payton, E. J.; Raabe, D.; Kaysser-Pyzalla, A.; Eggeler, G. On the Formation and Growth of Intermetallic Phases during Interdiffusion between Low-Carbon Steel and Aluminum Alloys. Acta Materialia 2011, 59 (4), 1586-1600. https://doi.org/10.1016/ j.actamat.2010.11.023.

[5]. Springer, H.; Kostka, A.; dos Santos, J. F.; Raabe, D. Influence of Intermetallic Phases and Kirkendall-Porosity on the Mechanical Properties of Joints between Steel and Aluminum Alloys. Materials Science and Engineering: A 2011, 528 (13-14), 4630-4642. https://doi.org/10.1016/ j.msea.2011.02.057.

[6]. Fedorov, V.; Weis, S.; Wagner, G. Mechanical and Microstructural Behavior of Brazed Aluminum / Stainless Steel Mixed Joints. IOP Conf. Ser.: Mater. Sci. Eng. 2016, 118, 012003. https://doi. org/10.1088/1757-899X/118/1/012003.
[7]. Fedorov, V.; Elßner, M.; Uhlig, T.; Wagner, G. Interfacial Microstructure and Mechanical Properties of Brazed Aluminum / Stainless Steel - Joints. IOP Conf. Ser.: Mater. Sci. Eng. 2017, 181, 012009. https://doi.org/10.1088/1757899X/181/1/012009.

[8]. Abood, A.; Mohammed, M. Furnace Brazing of AA5086 Aluminum Alloy with AISI 316L Stainless Steel by ER4047 and ER4043 Fillers. Journal of King Abdulaziz University-Engineering Sciences 2018, 29 (1). https://doi.org/10.4197/ Eng.29-1.3.

[9]. Yu, G.; Zou, T.; Chen, S.; Huang, J.; Yang, J.; Zhao, Z. Effect Mechanism of Ni Coating Layer on the Characteristics of Al/Steel Dissimilar Metal Brazing. Materials Characterization 2020, 167, 110518. https://doi.org/10.1016/ j.matchar.2020.110518.

[10]. Fedorov, V.; Uhlig, T.; Wagner, G. Influence of the Thickness of the Reaction Zone in Aluminum/ Stainless Steel Brazed Joints on the Mechanical Properties. Metals 2021, 11 (2), 217. https://doi. org/10.3390/met11020217.

[11].Chao, R. M.; Yang, J. M., Lay, S. R. Interfacial Toughness for the Shipboard Aluminum/Steel Structural Transition Joint. Marine Structure 1997, 10 (5), 353-362. https://doi.org/10.1016/S09518339(96)00018-4.

[12]. Meco, S.; Pardal, G.; Ganguly, S.; Williams, S.; McPherson, N. Application of Laser in Seam Welding of Dissimilar Steel to Aluminum Joints for Thick Structural Components. Optics and Lasers in Engineering 2015, 67, 22-30. https:// doi.org/10.1016/j.optlaseng.2014.10.006.

[13]. Basariya, M. I. R.; Mukhopadhyay, N. K. Structural and Mechanical Behaviour of AlFe Intermetallics. In Intermetallic Compounds - Formation and Applications; Aliofkhazraei, M., Ed.; InTech, 2018. https://doi.org/10.5772/ intechopen. 73944 . 